\title{
ZGLP1 wt Allele
}

National Cancer Institute

\section{Source}

National Cancer Institute. ZGLP1 wt Allele. NCI Thesaurus. Code C103980.

Human ZGLP1 wild-type allele is located in the vicinity of 19p13.2 and is approximately 5 $\mathrm{kb}$ in length. This allele, which encodes GATA-type zinc finger protein 1, plays a role in the negative regulation of transcription. 